\title{
Strategies of exploitation of mammalian reservoirs by Bartonella species
}

\author{
Hongkuan Deng ${ }^{1}$, Danielle Le Rhun', Jean-Philippe R Buffet ${ }^{1}$, Violaine Cotté ${ }^{1}$, Amanda Read ${ }^{2,3}$, Richard J Birtles ${ }^{2}$ \\ and Muriel Vayssier-Taussat ${ }^{1 *}$
}

\begin{abstract}
Numerous mammal species, including domestic and wild animals such as ruminants, dogs, cats and rodents, as well as humans, serve as reservoir hosts for various Bartonella species. Some of those species that exploit nonhuman mammals as reservoir hosts have zoonotic potential. Our understanding of interactions between bartonellae and reservoir hosts has been greatly improved by the development of animal models for infection and the use of molecular tools allowing large scale mutagenesis of Bartonella species. By reviewing and combining the results of these and other approaches we can obtain a comprehensive insight into the molecular interactions that underlie the exploitation of reservoir hosts by Bartonella species, particularly the well-studied interactions with vascular endothelial cells and erythrocytes.
\end{abstract}

\section{Table of contents}

1 Introduction

2 Dynamics of infection in mammalian reservoir hosts

3 Step 1: Infection prior to bacteraemia

3.1 The BadA/Vomp/Brp adhesions

3.2 The VirB/D4 type IV secretion system and its effector proteins

4 Step 2: Seeding of blood and extra cellular survival

5 Step 3: Erythrocyte encounter and adhesion

6 Step 4: Invasion of and persistence within erythrocytes

7 Conclusions

8 Competing interests

9 Author's contributions

10 Acknowledgments

11 References

\section{Introduction}

Bartonella species are small, curved, pleomorphic, fastidious, haemotropic Gram-negative bacteria that have specifically adapted to infect mammals. Although 26 Bartonella

\footnotetext{
* Correspondence: mvayssier@vet-alfort.fr

'USC INRA Bartonella et Tiques, ANSES, 23 Avenue du Général de Gaulle, 94700, Maisons-Alfort, France

Full list of author information is available at the end of the article
}

species or sub-species have been formally validated to date, many more, as yet partially characterized, await formal proposal. Bartonellae have been encountered in mammals all over the world, however the prevalence of infections and their public health and veterinary importance vary according to species and geographical region.

Bartonella species are transmitted between mammalian hosts by blood-feeding arthropods. Numerous, diverse arthropods have been implicated in the transmission of bartonellae, but each Bartonella species appears to exploit only one, or few, arthropod species. The role of arthropods in the natural cycle of bartonellae may extend beyond mere vectors; there is some evidence to support their role as additional reservoirs for the bacteria. Each Bartonella species also appears to be highly adapted to one or few mammalian reservoir hosts $[1,2]$ in which they establish a long-lasting intra-erythrocytic bacteraemia as the hallmark of infection [3]. This bacteraemia does not appear to cause immediate detriment to the host. In general, bartonellae provoke acute clinical manifestations only when accidentally introduced into the wrong host or when encountering immunocompromised individuals among reservoir populations.

The Bartonella genus lies among the alpha proteobacteria in proximity to the genus Brucella. Both genera are classified in the family Rhizobiales that also embraces a large number of taxa of plant-associated and environmental 
bacteria. Twenty-four Bartonella species have been validly described to date, with one species, Bartonella vinsonii, subdivided into three subspecies (Table 1). Inference of the phylogenetic relationships within the genus reveals the profound divergence of Bartonella bacilliformis, which lies alone on an "ancient" ancestral lineage (lineage 1), apart from the other Bartonella species. The remaining "modern" species form two further lineages, with lineage 2 containing the four ruminant-associated species (Bartonella bovis, Bartonella capreoli, Bartonella chomelii and Bartonella schoenbuchensis), and lineage 3 containing the remaining 19 species (Figure 1). Within lineage 3, Bartonella clarridgeiae is the outlier, and phylogenetic studies that have also included as yet only partially characterised bartonellae have suggested that this species is a representative of a fourth lineage within the genus $[4,5]$. The complete genome sequences of six Bartonella species $(B$. bacilliformis, B.clarridgeiae, Bartonella grahamii, Bartonella henselae, Bartonella quintana and Bartonella tribocorum) have been published to date, although efforts to sequence the genomes of all remaining species and numerous partially-characterised bartonellae are also underway. The sizes of the published genomes range from $1.45 \mathrm{Mb}$ to $2.62 \mathrm{Mb}[4,6]$.

B. bacilliformis and B. quintana are the two Bartonella species that appear to exploit humans as reservoir hosts (Table 1). Infections with B. bacilliformis only occur in the Andean region of South America [7,8], and this geographical distribution correlates with the range of the Lutzomyia species that are thought to transmit infections [8]. B. bacilliformis appears to be potentially the most pathogenic Bartonella species, provoking a remarkably bi-phasic disease referred to as bartonellosis. Acute bartonellosis manifests as Oroya fever, a disease which is characterized by a severe haemolytic anaemia effecting, in some cases, nearly $100 \%$ of erythrocytes. Fatality rates of up to $80 \%$ have been described in patients not receiving antibiotic treatment [9]. B. bacilliformis infections can also manifest as verruga peruana, characterized by vascular tumours that result from the massive

Table 1 Validated Bartonella species, their reservoir hosts, and their currently perceived medical relevance

\begin{tabular}{|c|c|c|}
\hline Bartonella species & Proven/suspected reservoir host & Evidence of human infections? \\
\hline B.alsatica & rabbits & yes \\
\hline B. bacilliformis & humans & yes \\
\hline B. birtlesii & small rodents & \\
\hline B.bovis & ruminants & \\
\hline B. capreoli & ruminants & \\
\hline B. chomelii & ruminants & \\
\hline B. clarridgeiae & felids & yes \\
\hline B. coopersplainensis & rats & \\
\hline B. doshiae & small rodents & \\
\hline B. elizabethae & rats & yes \\
\hline B. grahamii & small rodents & yes \\
\hline B. henselae & felids & yes \\
\hline B. japonica & small rodents & \\
\hline B. koehlerae & felids & yes \\
\hline B.peromysci & small rodents & \\
\hline B. queenslandensis & rats & \\
\hline B. quintana & humans & yes \\
\hline B. rattaustraliani & rats & \\
\hline B. schoenbuchensis & ruminants & \\
\hline B. silvatica & small rodents & \\
\hline B. talpae & moles & \\
\hline B. taylorii & small rodents & \\
\hline B. tribocorum & rats & yes \\
\hline B. vinsonii subsp. arupensis & small rodents & yes \\
\hline B. vinsonii subsp. berkhoffii & canids & yes \\
\hline B. vinsonii subsp. vinsonii & small rodents & yes \\
\hline
\end{tabular}




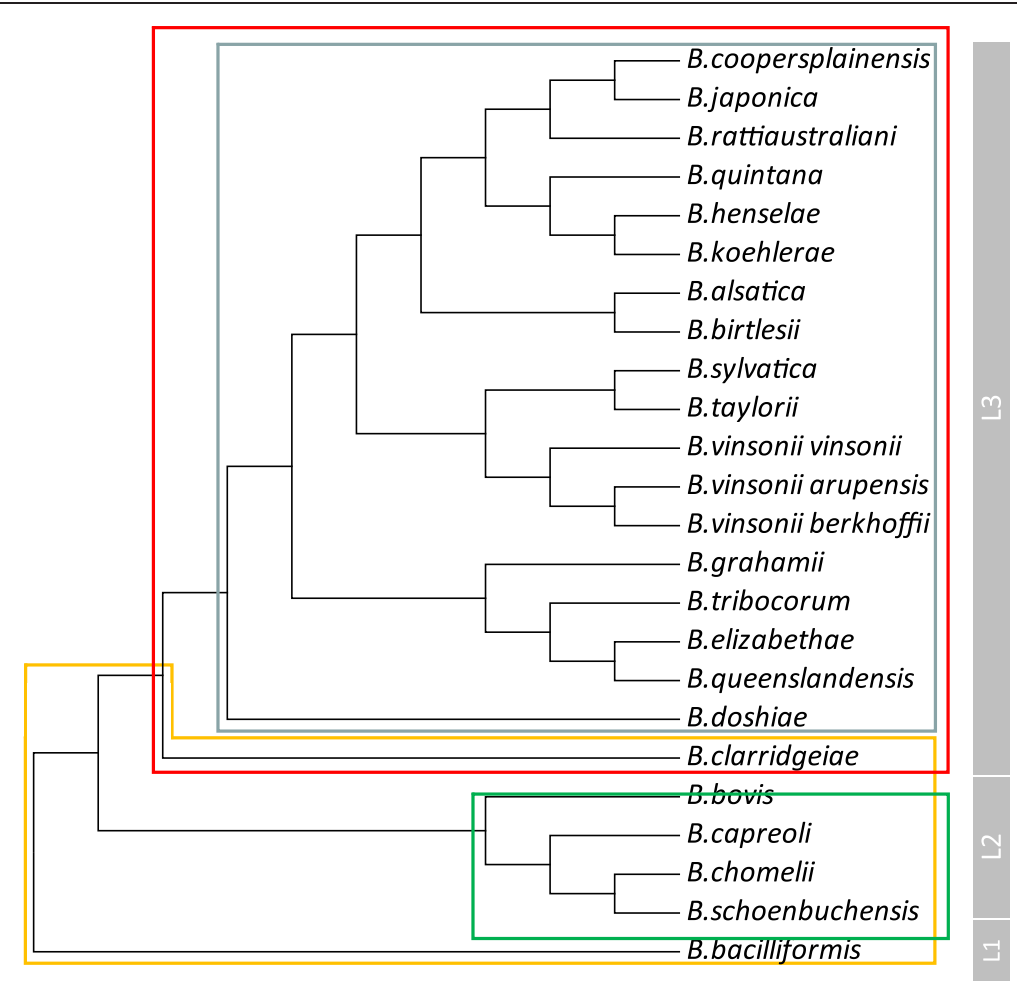

Figure 1 Molecular phylogenetic analysis of the 24 extant, validated Bartonella taxa inferred from alignment of partial (326 bp) gltA sequences. Evolutionary history was inferred by using the Maximum Likelihood method based on the Tamura-Nei model. The tress with the highest log likelihood is shown. Evolutionary analyses were conducted in MEGA5. Imposed on the tree are the distributions of the three T4SSS (red box = VirB/D4, blue box=Trw, green box: Vbh) and flagella (orange box) amongst the taxa. To the right of the tree is an indication of the three evolutionary lineages defined within the genus.

proliferation of endothelial cells and which can persist for more than one year $[7,8]$. Verruga peruana was probably recognized during pre-Columbian times, but its aetiology was not resolved until 1905, when B. bacilliformis was first isolated. B. quintana infections were first recognized during World War I in the form of trench fever (or five-day fever), but the bacterium was not isolated until 1961. Medical interest in B. quintana waned after World War II as infections became rare, but, at the end of the twentieth century, B. quintana re-emerged as a bacterium of public health importance with recognition of its role in persistent bacteraemia in the homeless, drug and alcohol addicts ("urban" trench fever) and refugees. Infection is usually characterized by a chronic intra-erythrocytic bacteraemia with few, mild, selflimiting symptoms [10], although more severe manifestations such as endocarditis and bacillary angiomatosis have also been reported [10]. B. quintana is transmitted by the human body louse (Pediculus humanus huma$n u s)$, an ectoparasite that is specific to humans but which only emerges when clothes remain unchanged and unwashed [11]. Thus, as with B. bacilliformis, vector behaviour is a key determinant in the epidemiology of $B$. quintana infections.
Numerous domestic and wild animals, including ruminants, felids, canids and rodents serve as reservoir hosts for various Bartonella species (Table 1) [2]. To date, evidence of zoonotic potential has been reported for 10 of these species (Table 1). In these reports, no evidence of an intra-erythrocytic presence of zoonotic bartonellae in infected humans has been reported [12]. Of the zoonosis-associated Bartonella species, $B$. henselae is the most frequently associated with human disease. $B$. henselae exploits felids, including domestic cats as reservoir hosts, between which infection is transmitted by cat fleas (Ctenocephalides felis) [13]. As is typical for reservoir hosts, cats usually do not develop any apparent symptoms of infection, which can persist for months or years [14]. B. henselae transmission from cats to humans is thought to occur primarily by the inoculation of infected flea faeces via cat scratches or bites [13], although there is also some evidence that infection can be acquired from ticks $[15,16]$. B. henselae can provoke a wide variety of clinical manifestations in humans, including, most commonly, lymphadenopathy (cat scratch disease), malaise, fever and splenomegaly that can persist for several months. Less frequently ( $<25 \%$ of cases) [17], more serious manifestations can occur, including angiomatosis 
(in immunocompromised patients), ocular disorder, encephalitis, meningitis, glomerulonephritis and endocarditis [12].

The other nine zoonosis-associated Bartonella species exploit a range of reservoir hosts; for example, B. vinsonii subspecies berkhoffii parasitizes canids (domestic dogs, coyotes and gray foxes) and Bartonella alsatica parasitizes rabbits. Others, such as B. grahamii are associated with woodland rodents (Table 1). In addition to their potential as human pathogens, numerous Bartonella species have been implicated in veterinary infectious diseases, including, most frequently, $B$. henselae and $B$. vinsonii subspecies berkhoffii. Many of the manifestations observed in cats and dogs are akin to those observed in humans.

\section{Dynamics of infection in mammalian reservoir hosts}

The life cycle of bartonellae in their reservoir hosts has been deduced through observations of naturally infected mammals and through experimental infections. In a seminal study [3], the evolution of infection of B.tribocorum in laboratory rats was monitored using a green fluorescent protein (GFP)-tagged bacterial strain in conjunction with microscopy and flow cytometry. This study found that, following intravenous injection (models incorporating a natural route of infection still remain generally elusive), bacteria could be initially detected in the blood but were soon cleared, only to reappear again between two and five days later. Only on reappearance were bartonellae observed inside erythrocytes, although only a small proportion of erythrocytes were infected. Erythrocytes were usually invaded by a single bacterium, which, once inside, replicated in a membrane-bound compartment over a period of several days until, on average, eight daughter cells were created. Replication then ceased and infected erythrocytes were shown to persist in circulation for several weeks. This process did not provoke symptoms in the infected rat [3]. Experiments using other animal models, such as a B. birtlesiimouse model [18-20], and a B. henselae-cat model [21] have yielded results that are akin to those observed in the B. tribocorum-rat model, suggesting a common infection mode for all Bartonella species in their respective animal reservoirs [22]. Furthermore, the kinetics of bacteraemia observed in these models were similar to those observed in captured naturally-infected animals (unpublished observations), which supports the reliability of results obtained from artificial routes of inoculation.

Our understanding of bartonellae/host interactions has been greatly improved by the development of molecular tools allowing large scale mutagenesis of Bartonella species such as B. tribocorum and B. birtlesii. The use of these tools in conjunction with judicious screening in relevant animal models (rats and mice respectively) has resulted in the identification of numerous genetic sequences, the integrity of which are necessary for the establishment of bacteraemia by bartonellae $[4,19]$. Those genetic sequences can be classified into six groups: (1) genes previously implicated in Bartonella infection of its mammalian hosts, (2) genes encoding cell envelope components, (3) genes encoding proteins involved in metabolism, (4) phage-related genes, (5) genes encoding proteins of unknown function and (6) intergenic regions. These data, when combined with the results of in vitro studies, allow us to piece together an overview of the molecular basis of reservoir host exploitation by Bartonella species.

\section{Step 1: Infection prior to bacteraemia}

As mentioned above, inoculation of a susceptible host appears to be primarily mediated by the introduction of infected vector faeces into cuts or scratches on the skin. However, the fate of infecting bacteria immediately following inoculation, prior to their appearance in the bloodstream, remains uncertain. Nonetheless, it is clear that bartonellae can colonise highly vascularised tissues like the liver and spleen during the first days of infection, as well as the vascular bed of the skin (for B. bacilliformis) [23]. A current opinion is that the vascular endotheliature serves as a primary niche for bartonellae. Indeed, bartonellae have been shown to have the ability to induce vasoproliferation, manifesting as verruga peruana (B. bacilliformis) or bacillary angiomatosis/peliosis hepatis (B. henselae and B. quintana). In many in vitro studies, bartonellae have been shown to be able to invade endothelial cell lines and/or interfere with their physiology [24-28] (see below). However, although the endothelial vasculature undeniably plays a role in the early stages of infection, there is some experimental evidence that other putative cell types, such as erythrocytic precursors, may also serve as a niche for infecting bartonellae [29]. This hypothesis, however, conflicts with data obtained using the GFP-B. tribocorum-rat model that clearly indicated that encounter with, and invasion of, erythrocytes occurs in the bloodstream [3]. Furthermore, we have been unable to find any evidence for the presence of bartonellae in erythrocyte precursors isolated from the bone marrow of $B$. birtlesii-infected mice, despite rigorous efforts to do so (unpublished observations).

It should also be borne in mind that evidence for vascular endothelial cell involvement in vivo is drawn primarily from pathological observations of B. bacilliformis-induced verruga peruana, and bacillary angiomatosis, a rare manifestation of $B$. henselae and $B$. quintana infections of humans. Endothelial cell colonisation has not yet been reported in asymptomatically infected reservoir hosts. 
Furthermore, pathological study of the vasculoproliferative lesions that characterise verruga peruana and bacillary angiomatosis suggests bartonellae are rather concentrated in proximity to the external surface of the endothelial cells, rather than within them. Thus, although we devote much of this review to the molecular basis of bartonellaevascular endothelial cell interactions, we do not discount the possibility that an as yet unidentified alternative primary niche may exist.

Exploitation of vascular endothelial cells by bartonellae involves binding to the cell surface, possible internalisation, then persistence within (or adjacent to) cells. To date, two major bacterial factors that play crucial roles in interacting with endothelial cells have been identified, namely the BadA/Vomp/Brp proteins and the VirB/D4 type four secretion system (T4SS) and its effectors. Other bacterial surface proteins, including the haembinding protein A (Pap31) and Omp43, have also been shown to interact with these cells. All of these factors have also been shown to be essential for the establishment of bacteraemia, as revealed by signature-tagged mutagenesis (STM) screening in both $B$. birtlesii-mouse and $B$. tribocorum-rat infection models, underlying the notion that bacteraemia is not the initial stage of the infection process.

\section{The badA/vomp/brp adhesions}

These proteins have different names in different Bartonella species, reflecting their concurrent discovery by independent groups of researchers. These proteins are referred to as bartonella adhesin A (BadA) in B. henselae [30], the variably-expressed outer membrane proteins (Vomps) in B. quintana [31], and bartonella repetitive protein A (BrpA) in B. vinsonii [32]. They are outer membrane proteins belonging to the trimeric autotransporter adhesin (TAA) family [33], that also includes the yersinia adhesin A (YadA) in Yersinia enterocolitica [34], the Haemophilus influenzae adhesin (Hia) as well as the haemophilus surface fibrils (Hsf) in H. influenzae [35], and the ubiquitous surface protein A (UspA) in Moraxella catarrhalis [36], all of which are considered to be virulence factors. All TAA family members share similar modular architectures, consisting of a head, neck, stalk, and Cmembrane anchor domains [34]. The C-membrane anchor domains define the TAA family and form trimers $[37,38]$. The size of these proteins varies from one species to another due to the number of TAA neck/stalk repeats, which can differ by up to four-fold. In B. henselae, the monomeric form of $\mathrm{Bad} \mathrm{A}$ is $328 \mathrm{kDa}$ in size [30]. In $B$. quintana, Vomps are encoded by a family of four genes, three of which are very similar to $b a d A$ (the exception being vompD). Although BrpA remains little studied, the functions of BadA and Vomp have been extensively explored using in vitro assays and experimental animal models. This work has demonstrated the pleiotropy of these proteins, implicating them in (1) mediation of binding of bartonellae to extracellular matrix proteins (collagens and fibronectin) and to endothelial cells, via $\alpha-5 \beta$ 1-integrins (2) circumvention of phagocytosis (3) mediation of angiogenesis via activation of hypoxia-inducible factor 1 (the key transcription factor in angiogenesis) in infected endothelial cells and via provocation of secretion of proangiogenic cytokines (e.g. vascular endothelial growth factor) [30,39]. BadA/Vomps are also involved in bacterial auto-aggregation [31,40], and probably in biofilm formation [41]. Interestingly, there is a marked variation in the expression of BadA between different B. henselae strains [42] and it is known that multiple in vitro passage of isolates results in the loss of BadA expression. Different genetic processes, such as single base deletions or insertions, or recombination events, can affect BadA expression resulting in the coexistence of phase variants expressing or not expressing BadA. This characteristic, when coupled with the observation that BadA-expressing strains grow slower than non-expressing strains, suggests that expression of BadA (which is an enormous molecule) is an extremely energetic process, and one which bartonellae will only continue whilst required to do so.

\section{The VirB/D4 T4SS and its effector proteins}

T4SSs consist of a multiprotein channel spanning inner and outer Gram-negative bacteria membranes and a surface filament extending from the bacterial envelope. The system mediates the transfer of protein or DNA substrates from a bacterial donor cell into various cell types (e.g. transfer of DNA into other bacteria by conjugation or transfer of bacterial effector molecules into eukaryotic cells). In pathogenic bacteria, this protein complex can be compared to a microscopic syringe that is used to inject effector proteins into target cells in order to subvert their physiology. T4SSs serve as key virulence factors for many important human pathogens including Helicobacter pylori, Legionella pneumophila, Bordetella pertussis, and Brucella melitensis [43]. Akin to other T4SSs, VirB/ D4 is a macromolecular complex of at least 10 components termed VirB2 to VirB11 and an associated substrate recognition receptor known as the T4 coupling protein (T4CP), named VirD4 (Figure 2).

The VirB/D4 T4SS was first identified in Bartonella species in 2000 as a result of characterization of the locus that encodes a $17 \mathrm{kDa}$ immunodominant protein in $B$. henselae [44]. Genetic comparison of this locus revealed that the $17 \mathrm{kDa}$ protein it encoded was a VirB5 homolog and further exploration of the locus revealed the presence of homologs of other members of the T4SS upstream and downstream of VirB5 [44,45]. The putative promoter region of the operon was also identified and its expression was shown to be induced when $B$. henselae was cultivated 


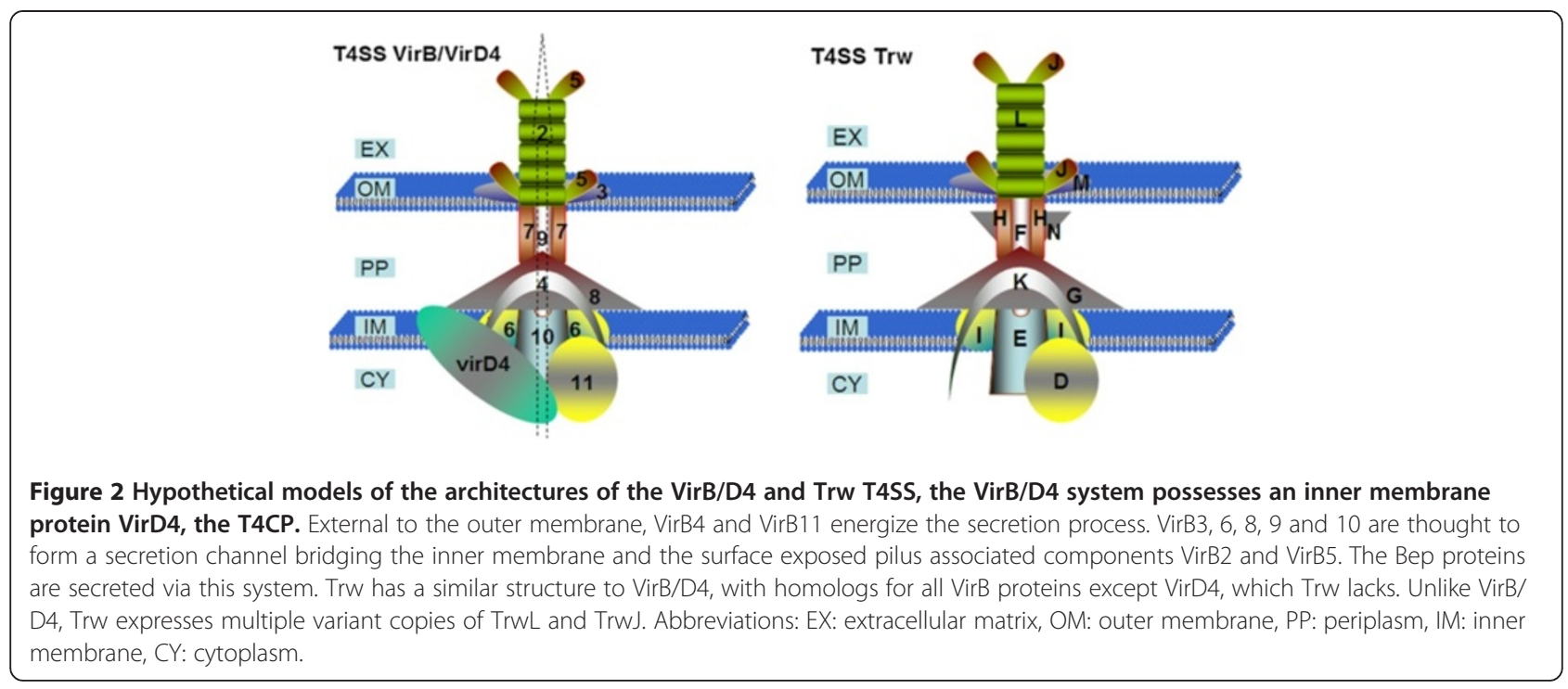

with human microvascular endothelial cells [46]. The operon was subsequently identified in other Bartonella species, and its necessity for host interaction was demonstrated using a $B$. tribocorum-rat and subsequently a $B$. birtlesii-mouse infection model $[4,19,47]$. Experimentation using these models revealed that although the VirB/D4 system was essential for exploitation of the primary niche, it was dispensable for the subsequent erythrocytic infection [48]. Recent studies have characterised seven genes encoding for effector proteins, termed bartonella effector proteins (Beps) A-G that are translocated by the VirB/D4 into endothelial cells [49] and are responsible for subverting their physiology. Indeed, in vitro experiments have indicated that $\mathrm{VirB} / \mathrm{D} 4$ and its effector proteins mediate a range of profound changes to parasitised endothelial cells [50,51], including (i) massive rearrangements of the actin cytoskeleton, resulting in the formation and internalisation of large bacterial aggregates by a unique "invasome" structure, (ii) NF- $\mathrm{k} \beta$-dependent pro-inflammatory activation leading to cell adhesion molecule expression and chemokine secretion, and (iii) inhibition of apoptotic cell death resulting in enhanced endothelial cell survival. Internalisation of bartonellae via invasomes (characterised by the formation of a bacterial aggregate on the cell surface, which is subsequently engulfed and internalised by an actindependant mechanisms [26]) is dependent on three VirB/ D4 effectors, BepC, BepG, and BepF [52,53]. BepA has been shown to inhibit endothelial cell apoptosis through upregulation of cAMP levels in the cytosol [49] and it also promotes capillary sprout formation in an endothelial spheroid infection model, whereas BepG inhibits such sprouting [54]. The functions of BepB, BepD and BepE are still to be elucidated. VirB/D4 appears to be part of the regulon of the BatR/S two component regulatory system, a global regulator that may be a key mediator of the physiological transition of bartonellae as they associate with endothelial cells [55].

A homolog of the VirB/D4 system, Vbh, has also been identified and all Bartonella species except B. bacilliformis possess at least one of these two T4SSs [4]. Comparative genomics have indicated that these systems were acquired by a common ancestor of lineage 2 and 3 Bartonella species following its divergence from lineage 1 that carries B. bacilliformis (Figure 1) [5]. Given the key roles attributed to these T4SSs, it is clear that its acquisition has resulted in fundamentally different bases of host exploitation by B. bacilliformis and the other Bartonella species. It has been proposed that species possessing the VirB/D4 or Vbh systems have attenuated virulence compared to $B$. bacilliformis, although this view remains controversial. Indeed, given that VirB/D4 and $\mathrm{Vbh}$ are so important for endothelial cell interaction in all Bartonella species, it is intriguing that the species in which it is absent, B. bacilliformis, is the species for which in vivo endothelial cell subversion is the most apparent.

Other bartonellae proteins have been shown to interact directly or indirectly with endothelial cells or the extracellular matrix. For instance, the outer membrane lipoprotein Omp43 is one of the bacterial proteins that binds most strongly to human umbilical vein endothelial cells (HUVEC) [56,57]. The Pap31 protein (haem-binding protein $\mathrm{A}$ ) of $\mathrm{B}$. henselae binds to fibronectin and promotes bacterial adhesion to endothelial cells [58]. As for VirB/D4 and Bad/Vomp, the disruption of these genes in the genomes of both B. birtlesii and B. tribocorum results in the non-appearance of bacteraemia in inoculated animal models [4,19]. Remarkably, Bartonella species also appear to secrete the heat-shock protein GroEL, which is a potent mitogen of HUVECs [59]. A 
holistic view of the synergy between all those virulence factors is schematically represented in Figure 3.

\section{Step 2: Seeding of blood and extra cellular survival}

In various animal models of infection, bacteraemia appears between 2 and 7 days post infection. It has been proposed that the appearance of bartonellae in the blood is orchestrated, occurring in the form of repeated, discreet waves rather than in a continuous stream [3]. Initially, the bacteria are extracellular, thus their passage must present them with a significant challenge in that they are fully exposed to the host immune system. Recently, we have shown that a $B$. birtlesii badA-knockout $(\triangle b a d A)$ mutant was sensitive to mouse serum, while the wildtype $B$. birtlesii, expressing active BadA, was resistant (Figure 4a). Since the $\triangle b a d A$ mutant was not killed by heat-inactivated serum (Figure $4 \mathrm{~b}$ ), we suspect that $B$. birtlesii BadA is involved in resistance to complement. In support of this hypothesis, we show that when wildtype $B$. birtlesii is grown in liquid media, the supernatant of this medium has anti-complement activity, but that this activity can be neutralized with anti-BadA antibodies (kindly provided by Professor Volkard Kempf, Goethe-Universität, Frankfurt am Main, Germany). These observations suggest that
BadA, or a part of BadA, could be secreted or released by B. birtlesii to counter the effects of complement, in a manner akin to that reported for the BadA homolog YadA in Yersinia enterocolitica [60]. We have also obtained evidence that bartonellae are capable of binding IgG Fc fragments and hypothesize that by doing so, the bacteria further facilitate their extracellular longevity by subversion of host humoral response. We observed that several Bartonella species had the capacity to bind Fc, and most could bind immunoglobins derived from a range of different mammals. Far-Western blotting indicates that the Fc binding capacity was mediated by a protein of approximately $65 \mathrm{kDa}$ size, and N-terminal sequencing of this protein demonstrates its identity with the heat shock response protein GroEL. Western blotting of $B$. henselae cellular fractions indicates that GroEL was located in the cytoplasm and in the inner and outer membrane of the cell, as previously demonstrated for B. bacilliformis [59]. Expression of recombinant $B$. henselae GroEL conferred an Fc binding capacity on Escherichia coli (Figure 5). A further mechanism by which bartonellae may counteract the threat of host immunity is via lipopolysaccharide (LPS) modification. The LPS of $B$. henselae possesses an unusual penta-acylated lipid A with a longchain fatty acid [61], a modification that may attenuate toll-like receptor
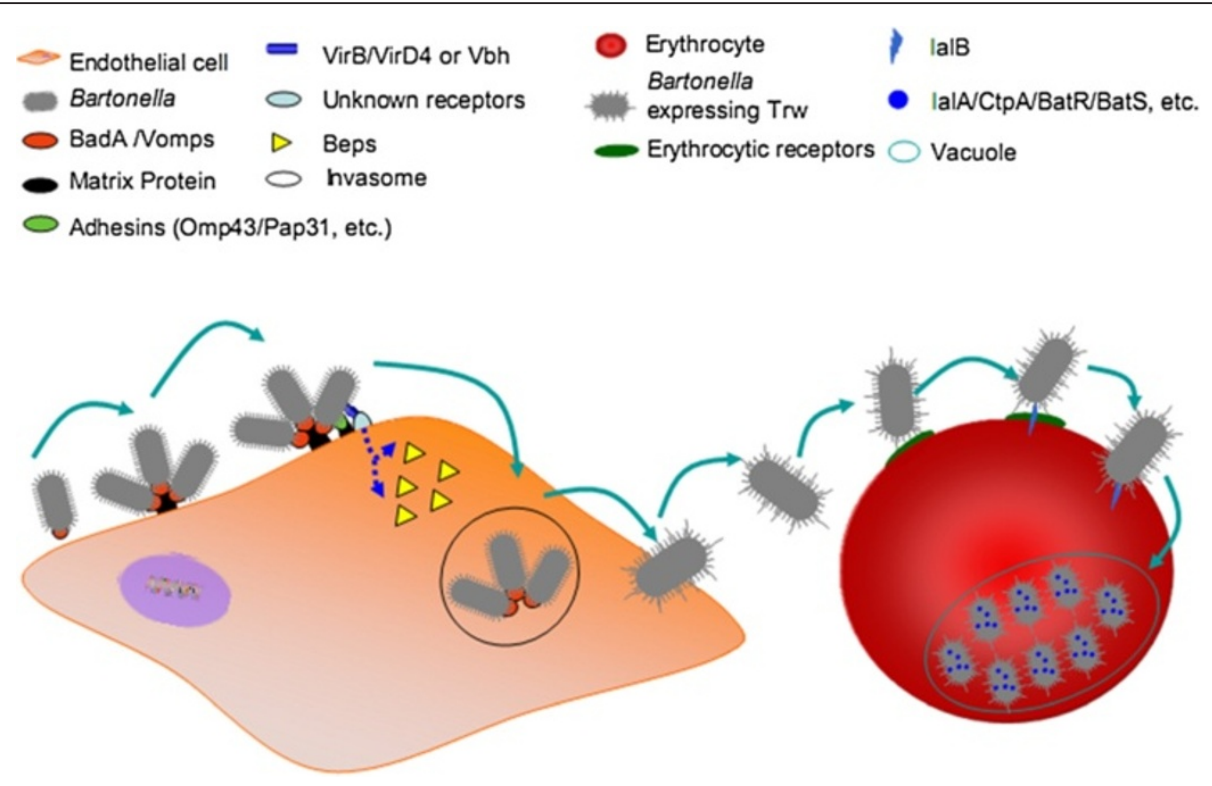

Figure 3 Holistic view of bartonellae interactions with endothelial cells and erythrocytes. Exploitation of vascular endothelial cells by bartonellae involves binding to the cell surface via BadANomps proteins as well as VirB/D4 and possible other adhesions as Omp43/pap31. VirB/ D4 and its effectors mediate massive rearrangements of the actin cytoskeleton, resulting in the formation of large bacterial aggregates by the invasome structure as well as inhibition of apoptosis leading to enhanced endothelial cell survival. The mechanisms of the passage of Bartonella spp. from endothelial cells to erythrocytes is unknown however, it appears that before infecting erythrocytes, the bacteria is free in the blood. Adherence to erythrocytes appears to be mediated by Trw (for most Bartonella species) or by flagella (for B. bacilliformis and the lineage 2 species). A erythrocyte is usually infected by a single bacterium, which once inside, replicates in a membrane-bound compartment then persists throughout the lifespan of the red blood cell. During this process, proteases lalA and CtpA are suspected to degrade misfolded proteins and to protect bacteria against stress. 


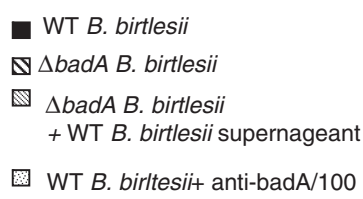

圈 WT B. birltesii+ anti-badA/100

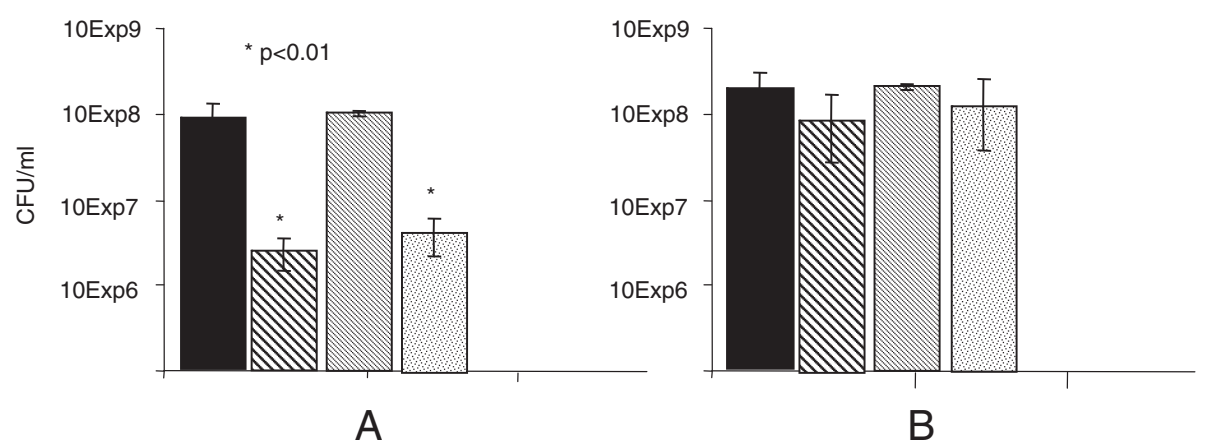

Figure 4 Role of $\boldsymbol{B}$. birtlesii BadA in complement inactivation. (A) Wild type (WT) and a badA-knockout mutant ( $\Delta$ badA) of B. birtlesii were incubated with foetal calf serum at $35^{\circ} \mathrm{C}$ in a $5 \% \mathrm{CO}_{2}$ atmosphere for one hour then plated onto Columbia blood agar plates. Plates were incubated at $35^{\circ} \mathrm{C}$ in a $5 \% \mathrm{CO} 2$ atmosphere for 5 days then colony forming units were counted. $\mathrm{N}=6+/-\mathrm{SE}$. (B) As described in (A) except that foetal calf serum was heated at $56^{\circ} \mathrm{C}$ for 30 min to inactivate the complement prior to use. $\mathrm{N}=6+/-\mathrm{SE}$.

(TLR) 4-mediated host response to bartonellae endotoxin $[61,62]$.

\section{Step 3: Erythrocyte encounter and adhesion}

The ability of bartonellae to exploit erythrocytes is key to their parasitic strategy and is almost unique amongst bacteria. Once inside erythrocytes, bartonellae occupy an immunologically privileged niche that, by virtue of its position in the circulatory system, facilitates not only persistence within the reservoir host but also uptake by haematophagous vectors.

There is, as yet, no evidence that Bartonella species are able to sense and specifically move towards circulating erythrocytes, hence we must currently assume that contact between bacterium and erythrocyte results from their chance encounter. Some Bartonella species possess flagella, which may facilitate their movement in blood plasma, but their absence from most species suggests they are not essential appendages and indeed, there is evidence that their value in host interaction occurs elsewhere during the course of infection (see below).

Adherence to erythrocytes by most Bartonella species appears to be mediated by the Trw T4SS and as yet uncharacterised receptors. Trw is the third T4SS found in bartonellae, and its importance in the establishment of intra-erythrocytic infections by bartonellae in reservoir hosts has been recognised for some time [63-65]. However, evidence for the direct role of Trw in erythrocyte infection has been only recently obtained following the development of an in vitro model for erythrocyte adherence and invasion [19]. In this study, we identified $B$. birtlesii genes required for erythrocyte infection by identifying, among STM mutants unable to induce bacteraemia in mice, those which could also not invade erythrocytes in vitro. From this screening, we identified nine invasion-deficient mutants. In seven of these, genes within the trw operon were disrupted, whereas in the other two, disruptions were located in the invasionassociated $i a l A / B$ locus (see below) and in $\operatorname{liv} G$, a putative $A B C$-transporter encoding gene. The nature of our screening resulted in the conclusion that the products of all these genes were essential for the adhesion to and/or invasion of erythrocytes rather than replication or persistence within them.

Trw shares homology with the broad-host-range conjugation system of R388 plasmid and was acquired by ancestral bartonellae via horizontal genetic transfer from phylogenetically distant bacterial species [66]. Unlike VirB/D4, the Trw T4SS lacks the coupling protein required for export of effectors, suggesting that it is no longer a secretion system [65]. The trw genes of Bartonella species are co-linear with the respective genes of plasmid R388 except for the presence of multiple tandem gene duplications of trwL (the virB2 homolog) and trwJ-I-H (the virB5, virB6 and virB7 homologs). The multiple copies of trwL and trw $J$ are thought to encode the suface-exposed pilus components of the T4SS, while the products of trwI and trwH are thought to be involved in pilus elongation and anchorage of the T4SS to the outer membrane (Figure 2). The presence of the multiple copies of these components indicates that they probably participate in the expression of variant pilus 


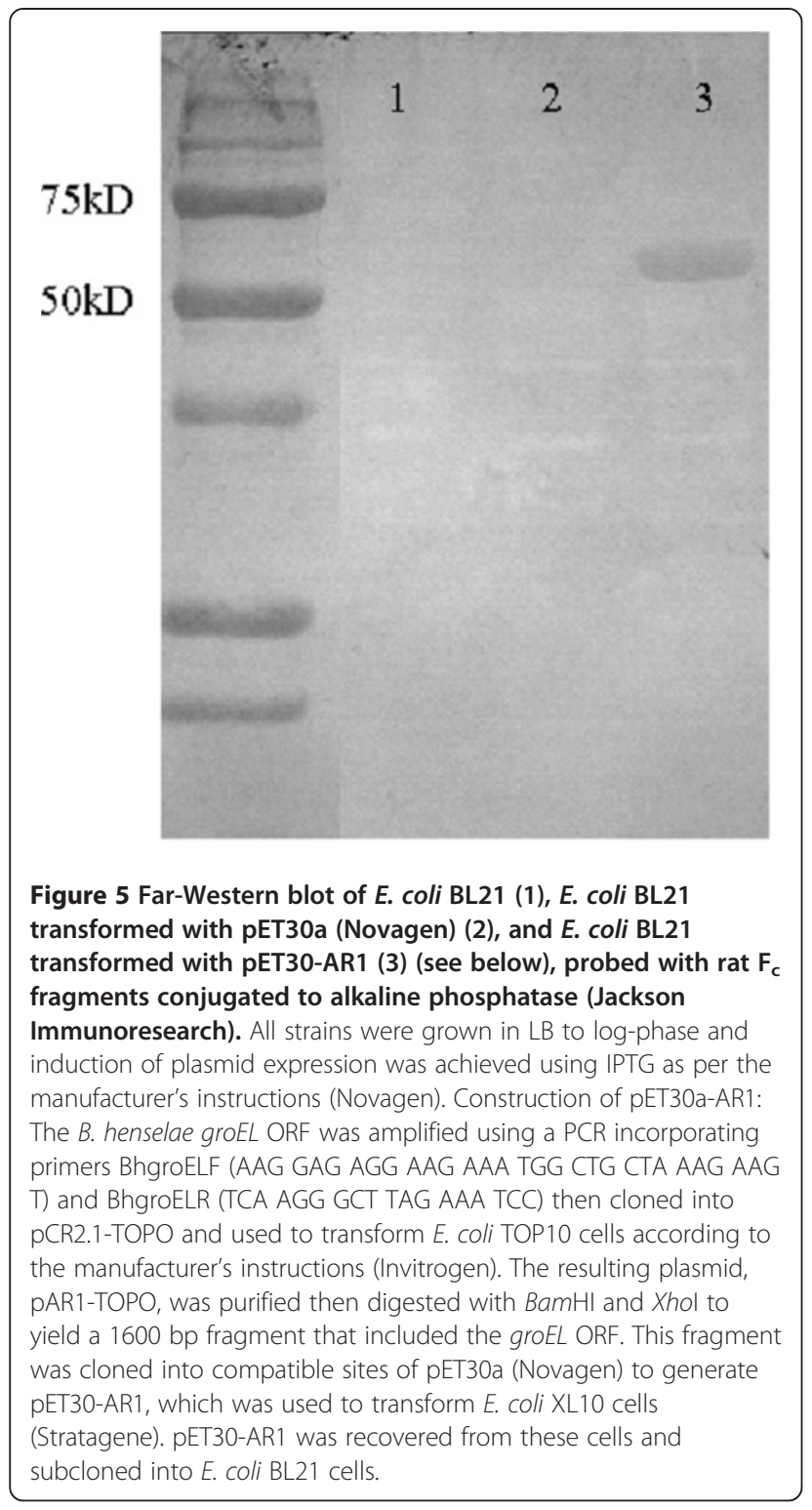

forms. It is not known if all trw genes are co-expressed and thus if numerous pili variants are concurrently present in the bartonellae population infecting a host or if differential expression of copies of these genes occurs, resulting in different pili variants being present on the bacterial cell surface during different stages of the infection process. It has been hypothesised that the presence of pili variants may facilitate the interaction with different erythrocyte receptors or with the variable forms of a specific receptor found across the breadth of the reservoir host population [64,67].

Our studies have also yielded evidence that Trw is a key determinant of bartonellae host specificity. As discussed above, although bartonellae can infect nonreservoir hosts, when they do so they are unable to establish an intra-erythrocytic bacteraemia. However, we were able to confer on $B$. henselae and B. quintana (which are naturally associated with only cats or humans respectively) the ability to interact with rat erythrocytes by transforming them to express the trw locus of the rat-adapted species B. tribocorum [19].

Even though erythrocyte parasitism is the hallmark of Bartonella species, the trw genes are not present in all Bartonella species, but are restricted to members of lineage 3 with the exception of this lineage's outlier, $B$. clarridgeiae (Figure 1). This distribution suggests that the Trw T4SS was horizontally acquired by a common ancestor of these members of lineage 3 [4]. Interestingly, the distribution of Trw and flagella among the Bartonella species is mutually exclusive (Figure 1 ), thus it has been proposed that following its acquisition, the function of Trw evolved to replace that performed by flagella. This hypothesis is supported by observations that the flagella of B. bacilliformis are involved in adhesion to and entry of erythrocytes [68-70].

\section{Step 4: Invasion of and persistence within erythrocytes}

Among the first virulence factors to be described for bartonellae were those encoded by the $i a l A / B$ locus in $B$. bacilliformis [71,72]. The survey of $B$. birtlesii genes involved in erythrocyte adherence/invasion, described above, also identified ialA and ialB. Early work demonstrated that the transformation of E. coli with B. bacilliformis ialA/B conferred the ability to invade erythrocytes [71] and more recently, we have shown that although deletion of ialB did not significantly affect adhesion of B. birtlesii to erythrocytes, it provoked a 10 fold decrease in bacterial entry into erythrocytes [19]. IalA has been characterized as a (de)nucleoside polyphosphate hydrolase of the MutT motif family and has homologs in other invasive bacteria such as Yersinia enterocolitica and Rickettsia prowazekii [73]. The precise role of IalA and its homologs is suspected to be the reduction of stress-induced dinucleotide levels during invasion, thereby enhancing pathogen survival [73]. IalB is a $19.9 \mathrm{kDa}$ protein with about $64 \%$ sequence similarity to the Yersinia enterocolitica protein Ail, a surface protein that plays a key role in mediating cell entry and serum resistance [60]. Intriguingly, B. bacilliformis IalB appears to be localised in the inner membrane [71] so it is unclear how it affects its role in erythrocyte entry. However, more recent work has suggested that in $B$. henselae, the protein is also associated with the outer membrane $[72,74]$. To add to this uncertainty, we have been able to detect IalB in B. birtlesii cryo-sections but not in intact bacteria, supporting the hypothesis that this protein is not surface exposed (Figure 6). Exploration of the determinants of ialB expression in B. bacilliformis has been reported and the patterns of expression observed under different conditions (temperature, $\mathrm{pH}$, oxidative 
stress, hemin limitation) suggest that the gene is upregulated in response to environmental cues signalling passage of the bacterium from the vector to the host, and also possibly at times when the bacterium is subjected to stress-inducing environmental conditions [75]. Despite the identification of entry-associated virulence factors, we currently have very little idea about how bartonellae enter erythrocytes. Given the unusual structure and physiology of erythrocytes, it is likely that bartonellae employ a mechanism of invasion that is different from those used for microbial entry into other cell types. How akin this mechanism is to, for example, those employed by Plasmodium species for erythrocyte invasion, remains to be seen. Microscopy has been used to monitor B. bacilliformis entry into erythrocytes, suggesting that the bacteria provoke then enter substantial deformations in erythrocyte membranes [68]. In this study, bacteria appeared to drive themselves into deep invaginations in the red cell surface, then membrane fusion at the necks of these invaginations led to the formation of intracellular vacuoles containing bacteria [68]. This process was considered, at least in part, to be mediated by the action of flagella. As discussed above, only very few Bartonella species express flagella, hence those without these appendages must have evolved an alternative entry strategy. There is also evidence that bartonellae produce an extracellular protein, termed deformation factor, which induces extensive invaginations, dentations and trenches in erythrocyte membranes [76,77].

Intra-erythrocytic replication starts within a vacuolar membrane immediately after invasion [3]. After several days, bacterial replication stops so that the number of intracellular bartonellae remains unchanged for the remaining life span of the erythrocyte. Within the red blood cell, bartonellae must not only scavenge for nutrients and also counter oxidative stress. Genomics has identified potential candidates that may be involved in these processes; proteases IalA and CtpA degrade misfolded proteins that arise from stress, and the genes encoding these proteins have been shown to be essential for the establishment of bacteraemia $[4,19]$. As yet, none of the molecular mechanisms underlying or regulating multiplication, growth control and then persistence of Bartonella species within erythrocytes have been identified.

Akin to many pathogenic bacteria, bartonellae utilizes host haem-containing proteins as a source of haem and iron. It has been shown that Bartonella species use a paralogous gene family of haem binding proteins (Hbps) and a haem uptake locus to sequester haem [78-80]. We have previously shown that $B$. birtlesii and $B$. tribocorum strains in which the genes encoding Hbps had been disrupted were unable to induce bacteraemia in their
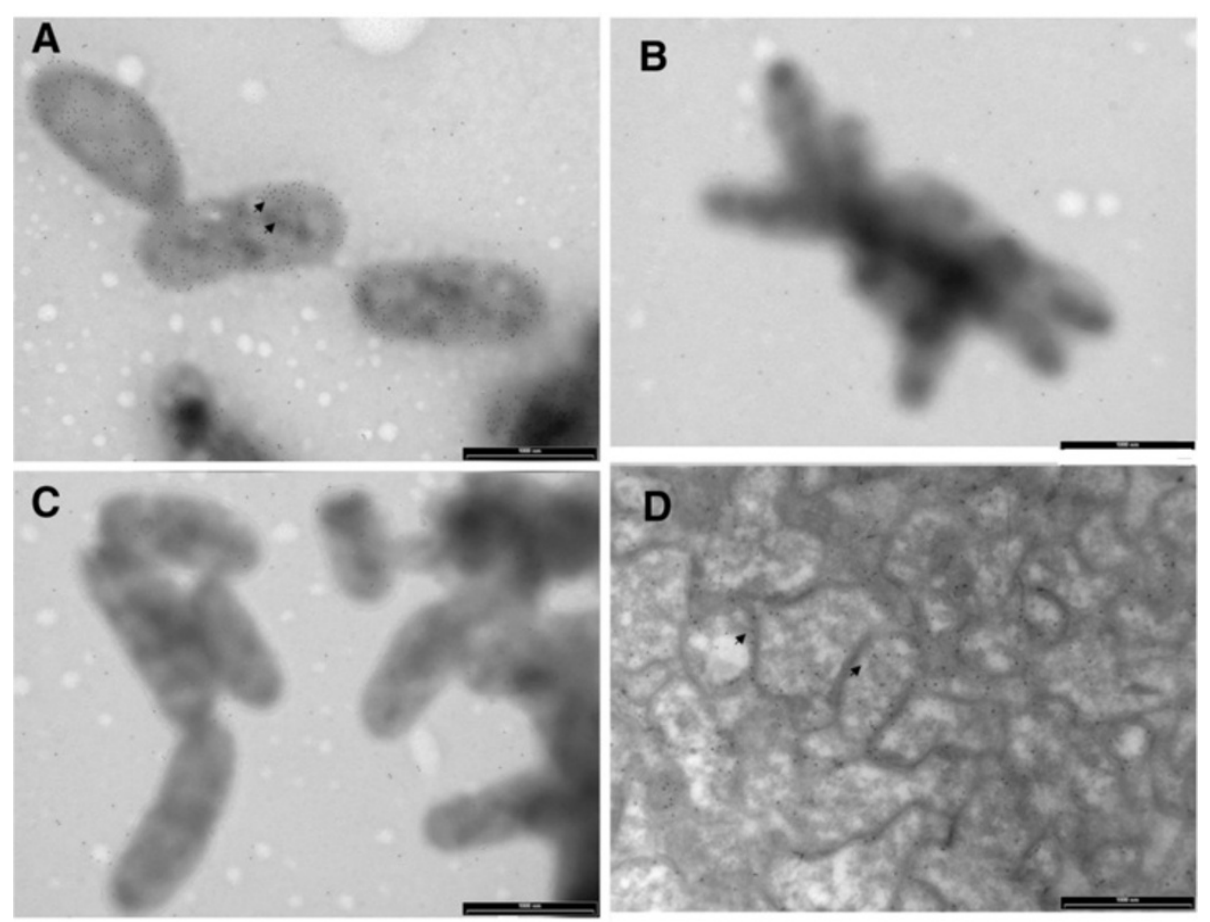

Figure $\mathbf{6}$ Localisation of IalB in B. birtlesii cells using immunogold staining. Primary antisera used on intact bacteria were whole cell $B$. birtlesii antiserum (A), negative serum (B), and B. birtlesii recombinant lalB antiserum (C). In (D) B. birtlesii recombinant lalB antiserum was used to localise lalB in cryosections of $B$. birtlesii cells. Arrows indicate the position of immunogold labels in these images. 
corresponding animal model, indicating the importance of these proteins in host exploitation by Bartonella species [4,19]. Both the $h b p$ genes and the haeminassociated locus (hut) are regulated by Irr, a regulatory protein involved in response to various stimuli including temperature shift, oxygen level and haemin concentration $[81,82]$. Further studies of those systems will contribute to our understanding of how bartonellae use the most abundant source of haem in the mammalian host, haemoglobin, and this contributes to its persistence within erythrocytes.

The rapid development of transcriptomic technologies should soon provide the means for exploration of the dynamics of bacterial gene expression during host interaction, thus we predict that the transcriptome of intraerythrocytic bartonellae will soon be available, helping us better understand the molecular means by which bartonellae thrive in their erythrocyte niche.

There is currently no evidence to suggest that infection of erythrocytes by Bartonella spp. has a significant effect on their physiology (life span and membrane integrity appear unchanged) [3]. However some subtle changes may occur; for example, during the period of erythrocyte invasion and multiplication, B. tribocoruminfected cells are cleared from circulation more rapidly than uninfected cells. However, once intracellular replication has ceased, this difference in clearance rates disappears [3]. These observations suggest that there are "recognizable" changes in erythrocyte structure or physiology during the early stages of their parasitism. These changes may result from the effects of deformin, as discussed above, with altered erythrocytes being filtered out by the spleen as demonstrated for Plasmodium spp. [83].

While most Bartonella species appear intent on not significantly altering the physiology of the circulating erythrocyte population, $B$. bacilliformis has the potential to provoke severe haemolytic anemia [84], although this pathology is not necessarily a consequence of infection. Evidence that haemolysis may be mediated by a contactdependant haemolysin has been presented [84], but this protein has yet to be fully characterized. Interestingly, although putative haemolysin-encoding genes are present in the B. bacilliformis genome, they are also found in the genomes of other Bartonella species.

\section{Conclusion}

The high prevalence of infections in mammals, and the potential threat posed to the health of humans, livestock and companion animals, warrants further exploration of the fundamental biology of Bartonella species. Despite a huge effort in the last 20 years to understand the mechanisms used by bartonellae to exploit their natural reservoir hosts, many areas of uncertainty remain and require further research.
In retrospect, one of the key studies that paved the way for recent advances was that completed a decade ago describing the dynamics of"natural" infection, as monitored using fluorescently-labelled bacteria [3]. The identification and quantification of distinct stages of infection, in tandem with the development of reliable tools for the genetic manipulation of bartonellae, has allowed significant advances to be made in our understanding of the molecular basis of bartonellae parasitism. However, despite this progress, and the ever increasing medical importance of bartonellae, it appears that today fewer and fewer scientists are studying these bacteria. It is unthinkable that research into the molecular basis of bartonellae-host interactions should falter now, with so many important and exciting questions still to be answered. For example, what is the fate of bacteria following inoculation? How do bacteria disseminate around the body and is the endothelial vasculature truly a primary niche for infection? Furthermore, why, on occasion, do bartonellae provoke angiogenesis? We also know nothing about how bartonellae regulate their intra-erythrocytic replication and persistence, what physiological changes they endure. We know little about the interaction between bartonellae and host immunity and thus little about the extent and importance of immunoregulation. Researchers also need to consider the role of arthropods in the bartonellae natural cycle and should perhaps incorporate "natural" inoculation by arthropods rather than by syringe into relevant animal models. In summary, the challenges for future years, are (1) to understand how, the unique infection strategy of bartonellae contributes to their remarkable epidemiological success in their reservoir hosts, and (2) to better assess if bartonellae have the potential to emerge as new zoonotic pathogens. In such a small field, a constructive means of helping to invigorate stimulating and high level science is collaboration between those laboratories with expertise in various key technical skills (experimental vector transmission, genetics, animal models) and those with the enthusiasm, but perhaps not all the means, to progress the field. Such initiatives should be encouraged and welcomed by all.

Competing interests

The authors declare that they have no competing interests.

Author's contributions

$H K D, R J B, M V T$ drafted the manuscript. DLR, CV carried out BadA experiments, AR carried out GroEL experiments, HD, MVT performed electron microscopy analysis. All authors read and approved the final manuscript.

\section{Acknowledgments}

The authors thank Dr S Bonnet and Dr JF Cosson for critical reading of the manuscript, the MIMA2 platform at the French National Institute for Agricultural Research in Jouy-en-Josas (Christine Longin and Sophie Chat) for technical help in electron microscopy and our colleagues working in the Bartonella field for generating much of the data presented in this manuscript. 


\section{Author details}

'USC INRA Bartonella et Tiques, ANSES, 23 Avenue du Général de Gaulle, 94700, Maisons-Alfort, France. ${ }^{2}$ School of Environment and Biological Sciences, University of Salford, Salford, Greater Manchester M5 4WT, United Kingdom. ${ }^{3}$ University of Texas San Antonio, One UTSA Circle, San Antonio TX 78249, USA.

Received: 8 July 2011 Accepted: 17 January 2012

Published: 27 February 2012

\section{References}

1. Vayssier-Taussat M, Le Rhun D, Bonnet S, Cotte V: Insights in Bartonella host specificity. Ann N Y Acad Sci 2009, 1166:127-132.

2. Chomel BB, Boulouis HJ, Breitschwerdt EB, Kasten RW, Vayssier-Taussat M, Birtles RJ, Koehler JE, Dehio C: Ecological fitness and strategies of adaptation of Bartonella species to their hosts and vectors. Vet Res 2009, 40:29.

3. Schulein R, Seubert A, Gille C, Lanz C, Hansmann Y, Piemont Y, Dehio C: Invasion and persistent intracellular colonization of erythrocytes. A unique parasitic strategy of the emerging pathogen Bartonella. J Exp Med 2001, 193:1077-1086.

4. Saenz HL, Engel P, Stoeckli MC, Lanz C, Raddatz G, Vayssier-Taussat M, Birtles R, Schuster SC, Dehio C: Genomic analysis of Bartonella identifies type IV secretion systems as host adaptability factors. Nat Genet 2007, 39: 1469-1476.

5. Engel P, Salzburger W, Liesch M, Chang CC, Maruyama S, Lanz C, Calteau A, Lajus A, Medigue C, Schuster SC, Dehio C: Parallel evolution of a type IV secretion system in radiating lineages of the host-restricted bacterial pathogen Bartonella. PLoS Genet 2011, 7:e1001296.

6. Alsmark CM, Frank AC, Karlberg EO, Legault BA, Ardell DH, Canback B, Eriksson AS, Naslund AK, Handley SA, Huvet M, La Scola B, Holmberg M, Andersson SG: The louse-borne human pathogen Bartonella quintana is a genomic derivative of the zoonotic agent Bartonella henselae. Proc Natl Acad Sci U S A 2004, 101:9716-9721.

7. Bass JW, Vincent JM, Person DA: The expanding spectrum of Bartonella infections: I. Bartonellosis and trench fever. Pediatr Infect Dis J 1997, 16:2-10.

8. Alexander B: A review of bartonellosis in Ecuador and Colombia. Am J Trop Med Hyg 1995, 52:354-359.

9. Ihler GM: Bartonella bacilliformis: dangerous pathogen slowly emerging from deep background. FEMS Microbiol Lett 1996, 144:1-11.

10. Foucault C, Brouqui P, Raoult D: Bartonella quintana characteristics and clinical management. Emerg Infect Dis 2006, 12:217-223.

11. Fournier PE, Minnick MF, Lepidi H, Salvo E, Raoult D: Experimental model of human body louse infection using green fluorescent proteinexpressing Bartonella quintana. Infect Immun 2001, 69:1876-1879.

12. Chomel BB, Kasten RW: Bartonellosis, an increasingly recognized zoonosis. J Appl Microbiol 2010, 109:743-750

13. Chomel BB, Kasten RW, Floyd-Hawkins K, Chi B, Yamamoto K, RobertsWilson J, Gurfield AN, Abbott RC, Pedersen NC, Koehler JE: Experimental transmission of Bartonella henselae by the cat flea. J Clin Microbiol 1996, 34:1952-1956.

14. Guptill L: Feline bartonellosis. Vet Clin North Am Small Anim Pract 2010, 40:1073-1090

15. Angelakis E, Pulcini C, Waton J, Imbert P, Socolovschi C, Edouard S, Dellamonica P, Raoult D: Scalp eschar and neck lymphadenopathy caused by Bartonella henselae after Tick Bite. Clin Infect Dis 2010, 50:549-551.

16. Cotte V, Bonnet S, Le Rhun D, Le Naour E, Chauvin A, Boulouis HJ, Lecuelle B, Lilin T, Vayssier-Taussat M: Transmission of Bartonella henselae by Ixodes ricinus. Emerg Infect Dis 2008, 14:1074-1080.

17. Windsor JJ: Cat-scratch disease: epidemiology, aetiology and treatment. Br J Biomed Sci 2001, 58:101-110.

18. Marignac G, Barrat F, Chomel B, Vayssier-Taussat M, Gandoin C, Bouillin C, Boulouis HJ: Murine model for Bartonella birtlesii infection: New aspects Comp Immunol Microbiol Infect Dis 2010, 33:95-107.

19. Vayssier-Taussat M, Le Rhun D, Deng HK, Biville F, Cescau S, Danchin A, Marignac G, Lenaour E, Boulouis HJ, Mavris M, Arnaud L, Yang H, Wang J, Quebatte M, Engel P, Saenz H, Dehio C: The Trw type IV secretion system of Bartonella mediates host-specific adhesion to erythrocytes. PLOS Pathog 2010, 6:e1000946.
20. Boulouis HJ, Barrat F, Bermond D, Bernex F, Thibault D, Heller R, Fontaine JJ, Piemont $Y$, Chomel BB: Kinetics of Bartonella birtlesii infection in experimentally infected mice and pathogenic effect on reproductive functions. Infect Immun 2001, 69:5313-5317.

21. Guptill L, Slater L, Wu CC, Lin TL, Glickman LT, Welch DF, HogenEsch H: Experimental infection of young specific pathogen-free cats with Bartonella henselae. J Infect Dis 1997, 176:206-216.

22. Birtles RJ: Bartonellae as elegant hemotropic parasites. Ann N Y Acad Sci 2005, 1063:270-279.

23. Arias-Stella J, Lieberman PH, Erlandson RA, Arias-Stella J Jr: Histology, immunohistochemistry, and ultrastructure of the verruga in Carrion's disease. Am J Surg Pathol 1986, 10:595-610.

24. Dehio C: Interactions of Bartonella henselae with vascular endothelial cells. Curr Opin Microbiol 1999, 2:78-82.

25. Dehio C: Bartonella interactions with endothelial cells and erythrocytes Trends Microbiol 2001, 9:279-285.

26. Dehio C, Meyer M, Berger J, Schwarz H, Lanz C: Interaction of Bartonella henselae with endothelial cells results in bacterial aggregation on the cell surface and the subsequent engulfment and internalisation of the bacterial aggregate by a unique structure, the invasome. J Cell Sci 1997, 110:2141-2154.

27. Dehio M, Quebatte M, Foser S, Certa U: The transcriptional response of human endothelial cells to infection with Bartonella henselae is dominated by genes controlling innate immune responses, cell cycle, and vascular remodelling. Thromb Haemost 2005, 94:347-361.

28. Pulliainen AT, Dehio C: Bartonella henselae: subversion of vascular endothelial cell functions by translocated bacterial effector proteins. Int J Biochem Cell Biol 2009, 41:507-510.

29. Mandle T, Einsele H, Schaller M, Neumann D, Vogel W, Autenrieth IB, Kempf $V A$ : Infection of human CD34+ progenitor cells with Bartonella henselae results in intraerythrocytic presence of $B$. henselae. Blood 2005, 106: 1215-1222.

30. Riess T, Andersson SG, Lupas A, Schaller M, Schafer A, Kyme P, Martin J, Walzlein $\mathrm{H}$, Ehehalt $\mathrm{U}$, Lindroos $\mathrm{H}$, Schirle M, Nordheim A, Autenrieth IB, Kempf VA: Bartonella adhesin a mediates a proangiogenic host cell response. J Exp Med 2004, 200:1267-1278.

31. Zhang P, Chomel BB, Schau MK, Goo JS, Droz S, Kelminson KL, George SS, Lerche NW, Koehler JE: A family of variably expressed outer-membrane proteins (Vomp) mediates adhesion and autoaggregation in Bartonella quintana. Proc Natl Acad Sci U S A 2004, 101:13630-13635.

32. Gilmore RD Jr, Bellville TM, Sviat SL, Frace M: The Bartonella vinsonii subsp. arupensis immunodominant surface antigen BrpA gene, encoding a 382-kilodalton protein composed of repetitive sequences, is a member of a multigene family conserved among bartonella species. Infect Immun 2005, 73:3128-3136.

33. Hoiczyk E, Roggenkamp A, Reichenbecher M, Lupas A, Heesemann J: Structure and sequence analysis of Yersinia YadA and Moraxella UspAs reveal a novel class of adhesins. EMBO J 2000, 19:5989-5999.

34. Biedzka-Sarek M, Salmenlinna S, Gruber M, Lupas AN, Meri S, Skurnik M: Functional mapping of YadA- and Ail-mediated binding of human factor $\mathrm{H}$ to Yersinia enterocolitica serotype 0:3. Infect Immun 2008, 76: 5016-5027.

35. St Geme JW, Cutter D 3rd: The Haemophilus influenzae Hia adhesin is an autotransporter protein that remains uncleaved at the $C$ terminus and fully cell associated. J Bacteriol 2000, 182:6005-6013.

36. Lafontaine ER, Cope LD, Aebi C, Latimer JL, McCracken GH Jr, Hansen EJ: The UspA1 protein and a second type of UspA2 protein mediate adherence of Moraxella catarrhalis to human epithelial cells in vitro. $J$ Bacteriol 2000, 182:1364-1373.

37. Meng G, Surana NK, St Geme JW 3rd, Waksman G: Structure of the outer membrane translocator domain of the Haemophilus influenzae Hia trimeric autotransporter. EMBO J 2006, 25:2297-2304.

38. Wollmann P, Zeth K, Lupas AN, Linke D: Purification of the YadA membrane anchor for secondary structure analysis and crystallization. Int J Biol Macromol 2006, 39:3-9.

39. Schulte B, Linke D, Klumpp S, Schaller M, Riess T, Autenrieth IB, Kempf VA: Bartonella quintana variably expressed outer membrane proteins mediate vascular endothelial growth factor secretion but not host cell adherence. Infect Immun 2006, 74:5003-5013. 
40. Kaiser PO, Riess $T$, Wagner $C L$, Linke $D$, Lupas $A N$, Schwarz H, Raddatz G, Schafer A, Kempf VA: The head of Bartonella adhesin A is crucial for host cell interaction of Bartonella henselae. Cell Microbiol 2008, 10:2223-2234.

41. Kyme P, Dillon B, Iredell J: Phase variation in Bartonella henselae. Microbiology 2003, 149:621-629.

42. Riess T, Raddatz G, Linke D, Schafer A, Kempf VA: Analysis of Bartonella adhesin $A$ expression reveals differences between various $B$. henselae strains. Infect Immun 2007, 75:35-43.

43. Christie PJ, Atmakuri K, Krishnamoorthy V, Jakubowski S, Cascales E: Biogenesis, architecture, and function of bacterial type IV secretion systems. Annu Rev Microbiol 2005, 59:451-485.

44. Sweger D, Resto-Ruiz S, Johnson DP, Schmiederer M, Hawke N, Anderson B: Conservation of the 17-kilodalton antigen gene within the genus Bartonella. Clin Diagn Lab Immunol 2000, 7:251-257.

45. Padmalayam I, Karem K, Baumstark B, Massung R: The gene encoding the $17-\mathrm{kDa}$ antigen of Bartonella henselae is located within a cluster of genes homologous to the virB virulence operon. DNA Cell Biol 2000 19:377-382

46. Schmiederer M, Arcenas R, Widen R, Valkov N, Anderson B: Intracellular induction of the Bartonella henselae virB operon by human endothelial cells. Infect Immun 2001, 69:6495-6502.

47. Seubert A, Schulein R, Dehio C: Bacterial persistence within erythrocytes: a unique pathogenic strategy of Bartonella spp. Int J Med Microbio/ 2002 291:555-560.

48. Schulein R, Dehio C: The VirB/VirD4 type IV secretion system of Bartonella is essential for establishing intraerythrocytic infection. Mol Microbio/ 2002, 46:1053-1067.

49. Schulein R, Guye P, Rhomberg TA, Schmid MC, Schroder G, Vergunst AC, Carena I, Dehio C: A bipartite signal mediates the transfer of type IV secretion substrates of Bartonella henselae into human cells. Proc Nat Acad Sci U S A 2005, 102:856-861.

50. Schmid MC, Scheidegger F, Dehio M, Balmelle-Devaux N, Schulein R, Guye $P$, Chennakesava CS, Biedermann B, Dehio C: A translocated bacterial protein protects vascular endothelial cells from apoptosis. PLOS Pathog 2006, 2:e115.

51. Schmid MC, Schulein R, Dehio M, Denecker G, Carena I, Dehio C: The VirB type IV secretion system of Bartonella henselae mediates invasion, proinflammatory activation and antiapoptotic protection of endothelial cells. Mol Microbiol 2004, 52:81-92.

52. Rhomberg TA, Truttmann MC, Guye P, Ellner Y, Dehio C: A translocated protein of Bartonella henselae interferes with endocytic uptake of individual bacteria and triggers uptake of large bacterial aggregates via the invasome. Cell Microbiol 2009, 11:927-945

53. Truttmann MC, Rhomberg TA, Dehio C: Combined action of the type IV secretion effector proteins BepC and BepF promotes invasome formation of Bartonella henselae on endothelial and epithelial cells. Cell Microbiol 2011, 13:284-299.

54. Scheidegger F, Ellner Y, Guye P, Rhomberg TA, Weber H, Augustin HG, Dehio C: Distinct activities of Bartonella henselae type IV secretion effector proteins modulate capillary-like sprout formation. Cell Microbiol 2009, 11:1088-1101.

55. Quebatte M, Dehio M, Tropel D, Basler A, Toller I, Raddatz G, Engel P, Huser S, Schein H, Lindroos HL, Andersson SG, Dehio C: The BatR/BatS twocomponent regulatory system controls the adaptive response of Bartonella henselae during human endothelial cell infection. J Bacteriol 2010, 192:3352-3367.

56. Burgess AW, Anderson BE: Outer membrane proteins of Bartonella henselae and their interaction with human endothelial cells. Microb Pathog 1998, 25:157-164

57. Burgess $A W$, Paquet $J Y$, Letesson JJ, Anderson BE: Isolation, sequencing and expression of Bartonella henselae omp43 and predicted membrane topology of the deduced protein. Microb Pathog 2000, 29:73-80.

58. Dabo SM, Confer AW, Anderson BE, Gupta S: Bartonella henselae Pap31, an extracellular matrix adhesin, binds the fibronectin repeat III13 module. Infect Immun 2006, 74:2513-2521.

59. Minnick MF, Smitherman LS, Samuels DS: Mitogenic effect of Bartonella bacilliformis on human vascular endothelial cells and involvement of GroEL. Infect Immun 2003, 71:6933-6942.

60. Kirjavainen V, Jarva H, Biedzka-Sarek M, Blom AM, Skurnik M, Meri S: Yersinia enterocolitica serum resistance proteins YadA and ail bind the complement regulator C4b-binding protein. PLOS Pathog 2008, 4: e1000140.

61. Zahringer $U$, Lindner B, Knirel YA, van den Akker WM, Hiestand $R$, Heine $H$ Dehio C: Structure and biological activity of the short-chain lipopolysaccharide from Bartonella henselae ATCC 49882 T. J Biol Chem 2004, 279:21046-21054.

62. Popa C, Abdollahi-Roodsaz S, Joosten LA, Takahashi N, Sprong T, Matera G, Liberto MC, Foca A, van Deuren M, Kullberg BJ, van den Berg WB, van der Meer JW, Netea MG: Bartonella quintana lipopolysaccharide is a natural antagonist of Toll-like receptor 4. Infect Immun 2007, 75:4831-4837.

63. Dehio C: Molecular and cellular basis of bartonella pathogenesis. Annu Rev Microbiol 2004, 58:365-390.

64. Dehio C: Infection-associated type IV secretion systems of Bartonella and their diverse roles in host cell interaction. Cell Microbiol 2008, 10 1591-1598.

65. Seubert A, Hiestand R, de la Cruz F, Dehio C: A bacterial conjugation machinery recruited for pathogenesis. Mol Microbiol 2003, 49:1253-1266.

66. Frank AC, Alsmark CM, Thollesson M, Andersson SG: Functional divergence and horizontal transfer of type IV secretion systems. Mol Biol Evol 2005, 22:1325-1336

67. Nystedt B, Frank AC, Thollesson M, Andersson SG: Diversifying selection and concerted evolution of a type IV secretion system in Bartonella. Mol Biol Evol 2008, 25:287-300.

68. Benson LA, Kar S, McLaughlin G, Ihler GM: Entry of Bartonella bacilliformis into erythrocytes. Infect Immun 1986, 54:347-353.

69. Scherer DC, DeBuron-Connors I, Minnick MF: Characterization of Bartonella bacilliformis flagella and effect of antiflagellin antibodies on invasion of human erythrocytes. Infect Immun 1993, 61:4962-4971.

70. Rolain JM, Novelli S, Ventosilla P, Maguina C, Guerra H, Raoult D: Immunofluorescence detection of Bartonella bacilliformis flagella in vitro and in vivo in human red blood cells as viewed by laser confocal microscopy. Ann N Y Acad Sci 2003, 990:581-584.

71. Mitchell SJ, Minnick MF: Characterization of a two-gene locus from Bartonella bacilliformis associated with the ability to invade human erythrocytes. Infect Immun 1995, 63:1552-1562.

72. Coleman SA, Minnick MF: Establishing a direct role for the Bartonella bacilliformis invasion-associated locus $B$ (lalB) protein in human erythrocyte parasitism. Infect Immun 2001, 69:4373-4381.

73. Cartwright $J$, Britton $P$, Minnick MF, McLennan AG: The lalA invasion gene of Bartonella bacilliformis encodes a (de)nucleoside polyphosphate hydrolase of the MutT motif family and has homologs in other invasive bacteria. Biochem Biophys Res Commun 1999, 256:474-479.

74. Chenoweth MR, Greene CE, Krause DC, Gherardini FC: Predominant outer membrane antigens of Bartonella henselae. Infect Immun 2004, 72: 3097-3105.

75. Coleman SA, Minnick MF: Differential expression of the invasionassociated locus B (ialB) gene of Bartonella bacilliformis in response to environmental cues. Microb Pathog 2003, 34:179-186.

76. Mernaugh G, Ihler GM: Deformation factor: an extracellular protein synthesized by Bartonella bacilliformis that deforms erythrocyte membranes. Infect Immun 1992, 60:937-943.

77. $\mathrm{Xu} \mathrm{YH,} \mathrm{Lu} \mathrm{ZY,} \mathrm{Ihler} \mathrm{GM:} \mathrm{Purification} \mathrm{of} \mathrm{deformin,} \mathrm{an} \mathrm{extracellular} \mathrm{protein}$ synthesized by Bartonella bacilliformis which causes deformation of erythrocyte membranes. Biochim Biophys Acta 1995, 1234:173-183.

78. Carroll JA, Coleman SA, Smitherman LS, Minnick MF: Hemin-binding surface protein from Bartonella quintana. Infect Immun 2000, 68 : 6750-6757.

79. Minnick MF, Sappington KN, Smitherman LS, Andersson SG, Karlberg O, Carroll JA: Five-member gene family of Bartonella quintana. Infect Immun 2003, 71:814-821.

80. Zimmermann R, Kempf VA, Schiltz E, Oberle K, Sander A: Hemin binding functional expression, and complementation analysis of Pap 31 from Bartonella henselae. J Bacterio/ 2003, 185:1739-1744.

81. Battisti JM, Sappington KN, Smitherman LS, Parrow NL, Minnick MF: Environmental signals generate a differential and coordinated expression of the heme receptor gene family of Bartonella quintana. Infect Immun 2006, 74:3251-3261.

82. Parrow NL, Abbott J, Lockwood AR, Battisti JM, Minnick MF: Function, regulation, and transcriptional organization of the hemin utilization locus of Bartonella quintana. Infect Immun 2009, 77:307-316. 
83. Buffet PA, Safeukui I, Deplaine G, Brousse V, Prendki V, Thellier M, Turner GD, Mercereau-Puijalon O: The pathogenesis of Plasmodium falciparum malaria in humans: insights from splenic physiology. Blood 2011, 117:381-392.

84. Hendrix LR: Contact-dependent hemolytic activity distinct from deforming activity of Bartonella bacilliformis. FEMS Microbiol Lett 2000, 182:119-124.

doi:10.1186/1297-9716-43-15

Cite this article as: Deng et al: Strategies of exploitation of mammalian reservoirs by Bartonella species. Veterinary Research 2012 43:15.

Submit your next manuscript to BioMed Central and take full advantage of:

- Convenient online submission

- Thorough peer review

- No space constraints or color figure charges

- Immediate publication on acceptance

- Inclusion in PubMed, CAS, Scopus and Google Scholar

- Research which is freely available for redistribution 